\title{
Parasitic fungi on selected trees in Dendrological Garden in Przelewice
}

\author{
Grzyby pasożytnicze występujące na wybranych drzewach \\ Ogrodu Dendrologicznego w Przelewicach
}

\author{
Jacek Kocanowski, Iwona Adamska
}

\section{Summary}

In 2010-2011 the studies on identification of parasitic fungi on selected tree species were carried out in the Dendrological Garden in Przelewice were performed. The research materials were above-ground parts of 9 plant species: Betula pendula, Betula maximowicziana, Cornus kousa, Acer pseudoplatanus, Acer negundo, Magnolia stellata, Robinia pseudoacacia, Populus tremula and Cerasus serrulata. As a result of the micological analyses 17 species of fungi were identified. The most numerous species (13) belonged to anamorphic fungi. The identified species of fungi belonged to 15 types. The largest number of types (11) belonged to anamorphic fungi. Basidiomycota and Ascomycota were represented by 2 types of fungi. Among others the following species were found: Diplodia atrata, Melasmia acerina, Uncinula bicornis, Melanconium betulinum, Stigmina carpophila, Phyllactinia guttata, Septoria cornicola, Colletotrichum gloeosporioides, Phyllosticta magnoliae, Asteroma frondicola, Melampsora populnea.

Key words: parasitic fungi, microscopic fungi, dendrology garden, Przelewice

\section{Streszczenie}

W latach 2010-2011 przeprowadzono badania, których celem było zidentyfikowanie grzybów zasiedlających wybrane gatunki drzew Ogrodu Dendrologicznego w Przelewicach. Materiałem badawczym były nadziemne części 9 gatunków roślin: brzoza brodawkowata (Betula pendula), brzoza maksimowicza (Betula maximowicziana), dereń kousa (Cornus kousa), klon jawor (Acer pseudoplatanus), klon jesionolistny (Acer negundo), magnolia gwiaździsta (Magnolia stellata), robinia akacjowa (Robinia pseudoacacia), topola osika (Populus tremula) i wiśnia piłkowana (Cerasus serrulata). W trakcie badań zidentyfikowano 17 gatunków grzybów należących do 15 rodzajów - najliczniej wystąpiły grzyby anamorficzne (13 gatunków). Największa liczba rodzajów (11) należała do grzybów anamorficznych, a podstawczaki i workowce reprezentowane były po 2 rodzaje grzybów. W trakcie badań znaleziono m.in.: Diplodia atrata, Melasmia acerina, Uncinula bicornis, Melanconium betulinum, Stigmina carpophila, Phyllactinia guttata, Septoria cornicola, Colletotrichum gloeosporioides, Phyllosticta magnoliae, Asteroma frondicola, Melampsora populnea.

Słowa kluczowe: grzyby pasożytnicze, grzyby mikroskopijne, ogród dendrologiczny, Przelewice

\footnotetext{
Zachodniopomorski Uniwersytet Technologiczny

Wydział Kształtowania Środowiska i Rolnictwa

Katedra Ochrony Roślin

Słowackiego 17, 71-434 Szczecin

jacek.kocanowski@zut.edu.pl
} 


\section{Wstęp / Introduction}

Ogród Dendrologiczny w Przelewicach położony jest na terenach rolniczych, na czarnoziemach pyrzyckich. Jego historia sięga początku XIX wieku. W latach 1801-1821 właścicielem Przelewic był August Heinrich von Borgstede, który przed rokiem 1814 zlecił założenie parku oraz wybudowanie pałacu.

Obecnie w skład Ogrodu Dendrologicznego wchodzi 12 głównych grup roślinnych znajdujących się wokół centralnie rozpościerającej się łąki. Arboretum w Przelewicach, jako jeden $z$ najstarszych $\mathrm{i}$ najpiękniejszych obiektów przyrodniczych województwa zachodniopomorskiego, przyciąga rocznie ponad 70 tysięcy turystów.

Mimo prowadzonych na terenie Ogrodu prac pielęgnacyjnych i zabiegów interwencyjnych na roślinach często stwierdzano objawy występowania chorób.

Celem badań było zidentyfikowanie grzybów zasiedlających wybrane gatunki drzew Ogrodu Dendrologicznego w Przelewicach.

\section{Materiały i metody / Materials and methods}

Badania przeprowadzono w latach 2010-2011 na terenie Ogrodu Dendrologicznego w Przelewicach. Przebadano 9 gatunków drzew liściastych. Były nimi: brzoza brodawkowata (Betula pendula), brzoza maksimowicza (Betula maximowicziana), dereń kousa (Cornus kousa), klon jawor (Acer pseudoplatanus), klon jesionolistny (Acer negundo), magnolia gwiaździsta (Magnolia stellata), robinia akacjowa (Robinia pseudoacacia), topola osika (Populus tremula) i wiśnia piłkowana (Cerasus serrulata). Próby roślinne pobierano raz w miesiącu, od kwietnia do października. Materiałem badawczym były nadziemne organy roślin wykazujące zmiany chorobowe związane $\mathrm{z}$ zasiedleniem i zarodnikowaniem przez grzyby mikroskopijne.

Z fragmentów chorujących liści pod mikroskopem stereoskopowym wycięto żyletką skrawki o długości 2-3 mm. Ścinki takie przenoszono za pomocą igły preparacyjnej na szkiełko podstawowe, na które wcześniej naniesiono kroplę kwasu mlekowego. Do analizy przystępowano po 3-4 dniach (w tym czasie kwas mlekowy prześwietlił struktury grzybów i tkanek żywiciela). Preparaty oglądano pod mikroskopem świetlnym. Grzyby oznaczono do rodzajów według opracowań Borowskiej (1986), Kochmana (1986) i Marcinkowskiej (2003), a do gatunków według przewodników Brandenburgera (1985) oraz Ellisa i Ellis (1985).

\section{Wyniki i dyskusja / Results and discussion}

W materiale znaleziono 17 gatunków grzybów. Najwięcej gatunków należało do grzybów anamorficznych (13 gatunków), a tylko po 3 taksony reprezentowały gromady Ascomycota i Basidiomycota. Zidentyfikowane grzyby należały do 15 rodzajów. Największa liczba rodzajów (11) należała do grzybów anamorficznych, a podstawczaki i workowce reprezentowane były przez 2 rodzaje grzybów z każdej grupy.

$\mathrm{Na} A$. negungo zidentyfikowano Diplodia atrata (Desm.) Sacc. Grzyb ten tworzył zanurzone w tkance, ciemnobrunatne do czarnych, zazwyczaj kuliste piknidia. Jego ujście znajdowało się na wybrzuszonym wzniesieniu.

Klon A. pseudoplatanus zasiedlały dwa gatunki grzybów: Melasmia acerina Lev. i Uncinula bicornis (Wallr. Ex Fr.) Lev. M. acerina jest sprawcą czarnej plamistości liści różnych gatunków klonu. Grzyb ten w zainfekowanych tkankach, w stromie tworzył przypłaszczone, czarne piknidia. Wyłożone one były warstwą jednokomórkowych, wydłużonych trzonków konidialnych. Jego konidia były jednokomórkowe, bezbarwne, wydłużone, elipsoidalne lub czasem zakrzywione. Według danych literaturowych teleomorfy tego grzyba należą do rodzaju Rhytisma (Marcinkowska 2003). Drugi z gatunków, Uncinula bicornis, jest sprawcą mączniaka prawdziwego. Jego grzybnia była biała i tworzyła pajęczynowaty lub wojłokowaty nalot. Grzyb ten tworzył zarodniki konidialne w postaci łańcuszków. Powstawały one na niewielkich trzonkach i były cylindryczne, elipsoidalne lub cylindryczno-elipsoidalne. Ciemnobrązowe, kuliste kleistotecja były opatrzone bezbarwnymi lub u nasady brązowymi, a na szczycie haczykowato lub laskowato zagiętymi przyczepkami.

$\mathrm{Na} B$. pendula stwierdzono występowanie czterech gatunków grzybów. Dwa gatunki: Alternaria alternata (Fr.) Keissler i Cladosporium cladosporioides (Fres.) de Vries występują pospolicie na zamierających fragmentach roślin. Grzyb Discula betulina powoduje zgorzelowa plamistość liści brzozy (Marcinkowska 2003). Choroba ta występuje pospolicie w Polsce (Marcinkowska 2003). Omawiany gatunek powodował powstawanie niewielkich czarnych lub brązowych plam na liściach. Silnie porażone blaszki żółkły i przedwcześnie opadały. Rdzawnikowiec Melampsoridium betulinum Kleb. powodował tworzenie się żółtych, drobnych plamek na górnej stronie liścia, a po ich dolnej stronie powstawanie skupisk urediniów. Dosyć rzadko na liściach obserwowano tworzenie teliów (ich obecność stwierdzano dopiero jesienią).

B. maximowicziana zasiedlana była tylko przez Melanconium betulinum C. Schmidt \& Kunze. Grzyb ten tworzył na porażonych liściach ciemne plamy. Pod skórką liścia powstawały czarne acerwulusy, z których wydostawały się owalne, jednokomórkowe, ciemnooliwkowe do brązowych zarodniki.

Na C. serrulata znaleziono jedynie Stigmina carpophila (Lev.) M.B. Ellis, który jest sprawcą dziurkowatości liści drzew pestkowych (Kochman 1986). Początkowo na liściach pojawiły się małe, jasnozielone plamki, które w miarę postępu choroby stały się brunatne $\mathrm{z}$ czerwoną obwódką. Następnie schorowane miejsca zasychały, zaś obumarła tkanka wypadała, tworząc regularne dziurki.

$\mathrm{Na}$ C. kousa zdiagnozowano dwa gatunki grzybów patogenicznych: Phyllactinia guttata (Wallr. Ex Fr.) Lev. i Septoria cornicola Desm. P. guttata - sprawca mączniaka prawdziwego, występował sporadycznie na omawianym żywicielu. Jego grzybnia rozwijała się na powierzchni liści żywiciela jako pajęczynowaty, biały nalot, a potem zanikła. Zarodniki konidialne tworzyły się pojedynczo 
Tabela 1. Występowanie grzybów pasożytniczych na 9 gatunkach drzew liściastych

Table 1. The presence of parasitic fungi on 9 species of deciduous trees

\begin{tabular}{|c|c|c|}
\hline \multirow{5}{*}{$\begin{array}{c}\text { Roślina } \\
\text { Plant }\end{array}$} & \multicolumn{2}{|c|}{ Rok - Year } \\
\hline & 2010 & 2011 \\
\hline & \multicolumn{2}{|c|}{ liczba wyizolowanych grzybów - number of isolated fungi } \\
\hline & 14 & 15 \\
\hline & \multicolumn{2}{|c|}{ gatunek grzyba - fungal species } \\
\hline $\begin{array}{l}\text { Brzoza brodawkowata } \\
\text { (Betula pendula) }\end{array}$ & $\begin{array}{c}\text { Alternaria alternata } \\
\text { Cladosporium cladosporioides } \\
\text { Discula betulina }\end{array}$ & $\begin{array}{c}\text { Alternaria alternata } \\
\text { Cladosporium cladosporioides } \\
\text { Discula betulina } \\
\text { Melampsoridium betulinum }\end{array}$ \\
\hline $\begin{array}{l}\text { Brzoza maksimowicza } \\
\text { (B. maximowicziana) }\end{array}$ & Melanconium betulinum & Melanconium betulinum \\
\hline $\begin{array}{l}\text { Dereń kousa } \\
(\text { Cornus kousa })\end{array}$ & $\begin{array}{c}\text { Phyllactinia guttata } \\
\text { Septoria cornicola }\end{array}$ & Phyllactinia guttata \\
\hline $\begin{array}{l}\text { Klon jawor } \\
\text { (Acer pseudoplatanus) }\end{array}$ & $\begin{array}{l}\text { Melasmia acerina } \\
\text { Uncinula bicornis }\end{array}$ & $\begin{array}{l}\text { Melasmia acerina } \\
\text { Uncinula bicornis }\end{array}$ \\
\hline $\begin{array}{l}\text { Klon jesionolistny } \\
\text { (A. negundo) }\end{array}$ & Diplodia atrata & Diplodia atrata \\
\hline $\begin{array}{l}\text { Magnolia gwiaździsta } \\
\text { (Magnolia stellata) }\end{array}$ & Colletotrichum gloeosporioides & Phyllosticta magnoliae \\
\hline $\begin{array}{l}\text { Robinia akacjowa } \\
\text { (Robinia pseudoacacia) }\end{array}$ & Septoria acaciae & Septoria acaciae \\
\hline $\begin{array}{l}\text { Topola osika } \\
\text { (Populus tremula) }\end{array}$ & $\begin{array}{c}\text { Asteroma frondicola } \\
\text { Cladosporium cladosporioides }\end{array}$ & $\begin{array}{c}\text { Asteroma frondicola } \\
\text { Cladosporium cladosporioides } \\
\text { Melampsora populnea }\end{array}$ \\
\hline $\begin{array}{l}\text { Wiśnia piłkowana } \\
\text { (Cerasus serrulata) }\end{array}$ & Stigmina carpophila & Stigmina carpophila \\
\hline
\end{tabular}

na długich trzonkach. Były one buławkowate, jajowate lub wrzecionowate. Grzyb S. cornicola powodował tworzenie się na liściach brązowych, kulistych drobnych plam. Na ich dolnej stronie znajdowały się czarne piknidia. Konidia były bezbarwne, długie, nitkowate, proste lub powyginane, zazwyczaj kilkukomórkowe. Teleomorfy grzyba z rodzaju Septoria zaliczane są do rodzaju Mycosphaerella (Marcinkowska 2003).

Na M. stellata zidentyfikowano dwa gatunki grzybów. Były to: Colletotrichum gloeosporioides (Penz.) Sacc. i Phyllosticta magnoliae Sacc. var cookei Sacc. C. gloeosporioides powoduje objawy zgorzeli (antraknozy) i stanowi stadium konidialne grzybów $\mathrm{z}$ rodzaju Glomerella (Kochman 1986). Tworzył on na zaatakowanych liściach dyskowate acerwulusy ukryte pod skórką. Pod nią znajdowały się trzonki konidialne zebrane w warstwę palisadowa. Były one bezbarwne i wydłużone. Na brzegach acerwulusa i wśród trzonków konidialnych występowały ciemno zabarwione (prawie czarne), kilkukomórkowe szczecinki. Konidia wydostawały się na zewnątrz w efekcie rozerwania skórki okrywającej acerwulus. Drugi z gatunków, P. magnoliae, powodował powstawanie na liściach plamistości, na których widoczne były czarne, drobne piknidia. Były one prawie w całości pogrążone w tkance gospodarza. Na powierzchni liścia wystawał tylko niewielki dziobek $\mathrm{z}$ ujściem. Konidia powstające w omawianych owocnikach były bezbarwne, jednokomórkowe, owalne lub cylindryczne.
Na liściach $P$. tremula występowały trzy gatunki grzybów: powszechnie występujące Asteroma frondicola (Fr. ex Ficinus \& Schubert) Morelet i Cladosporium cladosporioides oraz rzadziej spotykany Melampsora populnea (Pers.) Karst. Pierwszy gatunek powoduje plamistość liści topoli, a drugi jest taksonem kosmopolitycznym często zasiedlającym liście roślin drzewiastych oraz łodygi roślin zielnych. Grzyb $M$. populnea tworzył uredinia pod skórką liści. Po dojrzeniu były one nagie i posiadały główkowate urofizy. Urediniospory miały barwę pomarańczowożółtą, a ich ściany były bezbarwne i pokryte kolcami. Telia zazwyczaj powstawały pod skórką i zbudowane były $\mathrm{z}$ pojedynczej, zwartej warstwy jednokomórkowych, cylindrycznych teliospor. Ściana teliospor była gładka i zawierała pojedyncze otwory rostkowe.

Roślinę $R$. pseudoacacia zasiedlał tylko jeden gatunek grzyba - Septoria acaciae Neerg., powodujący powstawanie na liściach nieregularnych, dużych, rdzawych plam.

\section{Wnioski / Conclusions}

1. Masowe występowanie grzybów mikroskopijnych powodowało zahamowanie wzrostu oraz przedwczesne zrzucanie liści. 
2. Grzyby patogeniczne przyczyniły się do zmniejszenia walorów ozdobnych drzew w wyniku powodowania różnorodnych plamistości na liściach.
3. W roku 2010 znaleziono 14 gatunków grzybów, natomiast w 2011 roku wyizolowano 15 gatunków grzybów.

\section{Literatura / References}

Adamska I., Czerniawska B. 2007. Choroby grzybowe drzew i krzewów Szczecina. Prog. Plant Prot./Post. Ochr. Roślin 47 (2): $33-36$. Borowska A. 1986. Flora Polska. Grzyby (Mycota). Grzyby Niedoskonałe (Deuteromycetes). PWN, Warszawa-Kraków, 320 ss. Brandenburger W. 1985. Parasitische Pilze an Gefasspflanzen in Europa. Fischer, Stuttgart-New York, 1248 pp.

Ellis M.B., Ellis J.P. 1985. Microfungi on Land Plants. An Identification Handbook. Croom Helm, London-Sydney, 818 pp. Kochman J. 1986. Zarys Mikologii dla Fitopatologów. SGGW-AR, Warszawa, 428 ss.

Lesisz J. 2005. Ważniejsze choroby grzybowe występujące na drzewach i krzewach w Ogrodzie Botanicznym w Łodzi. Biuletyn Ogrodów Botanicznych 14: 93-100.

Marcinkowska J. 2003. Oznaczanie Rodzajów Grzybów Ważnych w Patologii Roślin. Fundacja Rozwój SGGW, Warszawa, 328 ss.

Przybył K. 2002. Ważniejsze choroby grzybowe i bakteryjne niektórych drzew i krzewów parkowych. Biuletyn Ogrodów Botanicznych 11: 9-20. 